\title{
Bacterial Streak and Bulb Rot of Onion: I. A Diagnostic Medium for the Semiselective Isolation and Enumeration of Pseudomonas viridiflava
}

\author{
R. Gitaitis, D. Sumner, and D. Gay, Department of Plant Pathology, D. Smittle and G. McDonald, Department of \\ Horticulture, and B. Maw, Department of Biological and Agricultural Engineering, University of Georgia, Tifton \\ 31793; W. C. Johnson III, Nematodes, Weeds, \& Crops Unit, USDA ARS, Tifton, GA 31793; and B. Tollner, De- \\ partment of Biological and Agricultural Engineering, and Y. Hung, Center of Food Safety and Quality, University \\ of Georgia, Athens 30602
}

\begin{abstract}
Gitaitis, R., Sumner, D., Gay, D., Smittle, D., McDonald, G., Maw, B., Johnson, W. C., III, Tollner, B., and Hung, Y. 1997. Bacterial streak and bulb rot of onion: I. A diagnostic medium for the semiselective isolation and enumeration of Pseudomonas viridiflava. Plant Dis. 81:897900 .

A semiselective, diagnostic agar medium (T-5) and low temperature incubation technique were developed for recovering Pseudomonas viridiflava from the environment or plant material. Medium T-5 contains the following per liter: $\mathrm{NaCl}, 5.0 \mathrm{~g} ; \mathrm{NH}_{4} \mathrm{H}_{2} \mathrm{PO}_{4}, 1.0 \mathrm{~g} ; \mathrm{K}_{2} \mathrm{HPO}_{4}, 1.0 \mathrm{~g}$; $\mathrm{MgSO}_{4} \cdot \mathrm{H}_{2} \mathrm{O}, 0.2 \mathrm{~g}$; D-tartaric acid, $3.0 \mathrm{~g}$; phenol red, $0.01 \mathrm{~g}$; agar, $20.0 \mathrm{~g}$; bacitracin, $10 \mathrm{mg}$; vancomycin, $6 \mathrm{mg}$; cycloheximide, $75 \mathrm{mg}$; novobiocin, $45 \mathrm{mg}$; penicillin $\mathrm{G}, 5 \mathrm{mg}$. The $\mathrm{pH}$ is adjusted to 7.4. Antibiotics are added aseptically after autoclaving. P. viridiflava recovery from artificially infested, field-soil (Tifton loamy-sand), with a cropping history of no onion production, was high, with a corresponding reduction of $99.99 \%$ of nontarget bacteria. However, soils from fields with a long history of onion production, near Vidalia, Georgia, contained significantly larger populations of background microflora that grew on medium T-5. Incubation at $5^{\circ} \mathrm{C}$ reduced contaminating microflora 1,000 - to 10,000 -fold with no reduction in recovery of the target organism. However, this low temperature incubation required an increased incubation period of 3 weeks and reduced the level of fluorescence of $P$. viridiflava.
\end{abstract}

Bacterial streak and rot of onion (Allium cepa L.), caused by Pseudomonas viridiflava (Burkholder) Dowson, has been a problem in onion-growing areas of Georgia since 1990 (6). Often, lesions initiate in the creases of flagged leaves as water-soaked, tan, oval spots. Lesions expand as dark green, water-soaked streaks down the leaf and darken with age until they are almost black. Soft rot frequently develops at the base of leaves above the neck of the bulb. Inner scales of infected bulbs initially are bright yellow, become reddish-brown with age, and occasionally are speckled with dark, "metallic" green globular material ( 1 to $3 \mathrm{~mm}$ diameter). The disease predisposes onion bulbs to other soft-rot pathogens as well as secondary or opportunistic organisms associated with postharvest decays. The disease is particularly severe under cool, wet conditions

Corresponding author: R. Gitaitis

E-mail: path4@tifton.cpes.peachnet.edu

Mention of a trademark, proprietary product, or vendor does not constitute a guarantee or warranty of the product by the University of Georgia and does not imply its approval to the exclusion of other products or vendors that may also be suitable.

Accepted for publication 21 April 1997.

Publication no. D-1997-0603-06R

(C) 1997 The American Phytopathological Society that occur in Georgia in the winter and early spring.

Sources of inocula for recent epidemics in onion have not been identified. $P$. viridiflava has a wide host range that includes alfalfa (Medicago sativa L.), birdsfoot trefoil (Lotus corniculatus L.) (15), bean (Phaseolus vulgaris L.) (4), poinsettia (Euphorbia pulcherrima Willd. ex Klotzsch) (22), tomato (Lycopersicon esculentum Mill.) (10), and other plants (24). It is not known if the onion pathogen survives in seed, soil, in association with another host, or as a resident on weeds. A laboratory technique for the detection and enumeration of $P$. viridiflava was needed for such epidemiological studies.

Numerous semiselective media, including BCBRVB (17), KBC (16), KFT (1), NPC (18), NPCC (20), and others $(2,11,12,21)$ have been reported for culture of fluorescent pseudomonads. Most of these media are modifications of King's medium $\mathrm{B}(\mathrm{KMB} ; 13)$ and were unsuitable for isolation of $P$. viridiflava from natural sources in Georgia. We describe a semiselective, diagnostic medium that suppresses growth of many nontarget microorganisms and serves as a suitable medium for growth and enumeration of $P$. viridiflava. A preliminary report of this work has been made (8).

\section{MATERIALS AND METHODS}

Sources of bacteria. Strains DD2, R2, and $91-1$ of $P$. viridiflava were isolated from onions in Georgia; strains PV 12322 and PV 12323 (original host bean) were obtained from the American Type Culture Collection (Rockville, MD) and strain PV 5777-4 (original host tomato) was obtained from J. B. Jones, University of Florida Gulf Coast Research \& Education Center (Bradenton, FL). Bacteria were maintained in $15 \%$ glycerol at $-73^{\circ} \mathrm{C}$ for long-term storage and in sterile tap water for routine use. Strains were grown and maintained on KMB (13) unless otherwise indicated.

Semiselective media composition. Semiselective media KBC (16), KFT (1), BCBRVB (17), and test media T-0 through T-5 were evaluated for growth and enumeration of $P$. viridiflava. In addition to the ingredients in $\mathrm{KMB}, \mathrm{KBC}$ contains boric acid, $1.5 \mathrm{~g}$; cephalexin, $80 \mathrm{mg}$; and cycloheximide, $200 \mathrm{mg}$ per liter; KFT contains basic fuchsin, $9 \mathrm{mg}$ and triphenyl-tetrazolium chloride, $0.15 \mathrm{mg}$ per liter; and BCBRVB contains bacitracin, $10 \mathrm{mg}$; vancomycin, $6 \mathrm{mg}$; rifampicin, $0.5 \mathrm{mg}$; cycloheximide, $75 \mathrm{mg}$; and benomyl, $250 \mathrm{mg}$ per liter.

The composition of media T0 to T5 were based on the utilization of $\mathrm{D}(-)$ tartrate (3) and modifications of NPC (18) and BCBRVB (17) and contained the following per liter: $\mathrm{NaCl}, 5.0 \mathrm{~g} ; \mathrm{NH}_{4} \mathrm{H}_{2} \mathrm{PO}_{4}$, $1.0 \mathrm{~g} ; \mathrm{K}_{2} \mathrm{HPO}_{4}, 1.0 \mathrm{~g} ; \mathrm{MgSO}_{4} \cdot 7 \mathrm{H}_{2} \mathrm{O}, 0.2 \mathrm{~g}$; $\mathrm{D}(-)$ tartaric acid, $3.0 \mathrm{~g}$; phenol red, 0.01 $\mathrm{g}$; and agar, $15.0 \mathrm{~g}$. The $\mathrm{pH}$ was adjusted to 7.4 with $1.0 \mathrm{~N} \mathrm{NaOH}$. In addition, $\mathrm{T}-1$ contained penicillin $\mathrm{G}, 50 \mathrm{mg}$; novobiocin, $45 \mathrm{mg}$; and cycloheximide, $75 \mathrm{mg}$ per liter; T-2 contained bacitracin, $10 \mathrm{mg}$; vancomycin, $6 \mathrm{mg}$; and cycloheximide, $75 \mathrm{mg}$ per liter; T-3 contained bacitracin, $10 \mathrm{mg}$; rifampicin, $0.5 \mathrm{mg}$; and cycloheximide, 75 mg per liter; T- 4 contained bacitracin, 10 $\mathrm{mg}$; vancomycin, $6 \mathrm{mg}$; rifampicin, 0.5 $\mathrm{mg}$; and cycloheximide, $75 \mathrm{mg}$ per liter; and T-5 contained bacitracin, $10 \mathrm{mg}$; vancomycin, $6 \mathrm{mg}$; novobiocin, $45 \mathrm{mg}$; penicillin G, $50 \mathrm{mg}$; and cycloheximide, $75 \mathrm{mg}$ per liter.

Plating efficiency and selectivity assessments. Thirty milliliters of 24-h-old nutrient-broth, shake cultures were centrifuged at $3,000 \times g$ for $20 \mathrm{~min}$ and pellets were suspended in phosphate-buffered saline (PBS) $0.01 \mathrm{M} \mathrm{K} \mathrm{HPO}_{4}-\mathrm{KH}_{2} \mathrm{PO}_{4}$, $0.85 \% \mathrm{NaCl} ; \mathrm{pH}$ 7.3. Bacterial suspensions were adjusted to $50 \%$ transmittance at 600 
nm using a spectronic 20 (Bausch \& Lomb, Rochester, NY) (7). Serial dilutions (1:9) were made in PBS and aliquants $(0.1$ $\mathrm{ml}$ ) of selected dilutions were spread on the surface of test media. Colonies were counted after 3 to 5 days' incubation at $25^{\circ} \mathrm{C}$. Plating efficiencies were determined by enumerating colonies of $P$. viridiflava on test media, dividing by number of colonies on KMB agar, and multiplying the quotient by 100 .

Selectivity was assessed by assaying soil artificially infested with $P$. viridiflava. Soil samples (Tifton loamy-sand [fine loamy, siliceous, thermic Plinthic Kandiudults]) were collected from fields in Montgomery, Tift, and Toombs counties, Georgia. The Toombs County site (Site A) had been in an onion-soybean multi-crop, rotation for 5 years and had a history of onions for a minimum of 20 years. The Montgomery County site (Site B) had a history of onionsummer fallow for 5 years. The Tift County site had no history of onion for the past 20 years and was fallow at the time of sampling. Soil cores (80 cores, 2.5 -cm diameter, $10 \mathrm{~cm}$ deep) were collected from across fields at each site. Soils from each area of a field were mixed thoroughly and divided into two portions for each site. Ten-gram samples from each portion were suspended in separate sterile beakers containing $100 \mathrm{ml}$ of PBS. Aliquants $(1.0 \mathrm{ml})$ of suspensions of $P$. viridiflava were prepared as above and added to one of the soil portions (amended) from each site to produce an estimated population of $10^{3}$ $\mathrm{CFU} / \mathrm{ml} / \mathrm{g}$ of soil. Serial dilutions (1:9) were made in PBS, and aliquants $(0.1 \mathrm{ml})$ from each portion (amended and nonamended) were spread on the surface of test media. Colonies were counted after 3 to 5 days' incubation at $25^{\circ} \mathrm{C}$. Tests were replicated three times.

Incubation at different temperatures was evaluated to reduce numbers of colonies of nontarget, saprophytic microorganisms. Aliquants of dilutions of known populations of $P$. viridiflava were spread on KMB and T-5 and incubated at 30, 25, 15, 10, and $5^{\circ} \mathrm{C}$. Plating efficiencies were determined as above. All tests were replicated three times.
Identification of bacteria. Colonies picked from test media were characterized by gram-reaction (23), production of a water-soluble, fluorescent pigment on KMB (13), ice nucleation activity (9), utilization of DL-lactate $(5,9)$, D-tartrate $(3,5)$, sucrose $(3,5)$, presence of oxidase
$(5,14)$, and absence of arginine dihydrolase (14). Ability to rot onion was evaluated by asceptically slicing peeled onion bulbs, stabbing the tissue with a bacteriological loop covered with bacteria, incubating them at $28^{\circ} \mathrm{C}$, and observing for soft rot symptoms after 24 to $72 \mathrm{~h}$.

Table 2. Recovery of a known population $\left(\sim 10^{3} \mathrm{CFU} / \mathrm{ml}\right)$ of Pseudomonas viridiflava (pv. 91-1) on King's medium B (KMB) and T-5 semiselective agar from six different soil samples ${ }^{\mathrm{a}}$ from Montgomery, Tift, and Toombs counties ${ }^{\mathrm{b}}$, Georgia

\begin{tabular}{lcrc}
\hline Medium & Soil & Source & Pv. 91-1 population recovered $\mathbf{c}^{\mathbf{c} \mathbf{d}}$ \\
\hline KMB & A & Tift & $\mathrm{NE}$ \\
& $\mathrm{B}$ & Tift & $\mathrm{NE}$ \\
& C & Tift & $\mathrm{NE}$ \\
& Tift & Toombs & $\mathrm{NE}$ \\
& E & Montgomery & $\mathrm{NE}$ \\
T-5 & F & Tift & $2.5 \times 10^{3}$ \\
& A & Tift & $1.6 \times 10^{3}$ \\
& B & Tift & $1.5 \times 10^{3}$ \\
& C & Toombs & $5.9 \times 10^{3}$ \\
& D & NE \\
& E & Montgomery & $\mathrm{NE}$ \\
\hline
\end{tabular}

a $10 \mathrm{~g}$ nonsterile soil; $100 \mathrm{ml}$ PBS $\left(0.01 \mathrm{M} \mathrm{K}_{2} \mathrm{HPO}_{4}-\mathrm{KH}_{2} \mathrm{PO}_{4}, 0.85 \% \mathrm{NaCl}\right.$; $\left.\mathrm{pH} 7.3\right)$; and $1.0 \mathrm{ml}$ of a bacterial suspension containing $10^{5} \mathrm{CFU}$ of pv. $91-1 / \mathrm{ml}$ PBS (final approximate concentration of $10^{3} \mathrm{CFU} / \mathrm{ml}$ ) were mixed and agitated on a rotary shaker at $150 \mathrm{rpm}$ for $10 \mathrm{~min}$.

${ }^{\mathrm{b}}$ Cropping history of soils from Tift County did not include onions, whereas the histories of soils in Montgomery and Toombs counties included continuous cropping of onions for 10 and 16 years, respectively.

${ }^{c}$ Values represent recovered populations of $P$. viridiflava determined by serially diluting soil-bacterial suspensions in PBS to $10^{-1}$, and $0.1 \mathrm{ml}$ from the source and $10^{-1}$ dilutions were spread plate on each medium. Values are the mean of three replications. $\mathrm{NE}=$ no estimate due to interference by abundant growth of nontarget microorganisms.

${ }^{\mathrm{d}}$ Two representative CFU were picked from each plate of T-5 $(n=48)$ and were streaked to obtain pure cultures on plates of KMB and then were characterized for oxidase, arginine dihydrolase, ice nucleation and utilization of dl-lactate, $\mathrm{D}(-)$ tartrate, and sucrose.

Table 3. Effect of incubation temperature $\left({ }^{\circ} \mathrm{C}\right)$ on growth of Pseudomonas viridiflava on King's medium B (KMB) and T-5 semiselective agar

\begin{tabular}{lcccccc}
\hline & & \multicolumn{5}{c}{ Log $_{\mathbf{1 0}}$ population of $\boldsymbol{P}$. viridiflava } \\
\cline { 3 - 6 } Strain & Medium & $\mathbf{3 0}^{\circ} \mathbf{C}$ & $\mathbf{2 5}^{\circ} \mathbf{C}$ & $\mathbf{1 5}^{\circ} \mathbf{C}$ & $\mathbf{1 0}^{\circ} \mathbf{C}$ & $\mathbf{5}^{\circ} \mathbf{C}$ \\
\hline DD2 & KMB & 8.9 & 8.9 & 8.8 & 8.8 & 8.8 \\
DD2 & T-5 & 8.6 & 8.8 & 8.7 & 8.9 & 8.8 \\
R2 & KMB & 8.7 & 8.8 & 8.8 & 8.9 & 8.9 \\
R2 & T-5 & 8.8 & 8.8 & 8.7 & 8.8 & 8.7 \\
$91-1$ & KMB & 8.9 & 8.9 & 8.9 & 8.9 & 8.9 \\
91-1 & T-5 & 8.8 & 8.9 & 8.9 & 8.8 & 8.8 \\
\hline
\end{tabular}

${ }^{a}$ Bacteria were grown in nutrient broth for $24 \mathrm{~h}$, harvested by centrifugation, resuspended in PBS $\left(0.01 \mathrm{M} \mathrm{K}_{2} \mathrm{HPO}_{4}-\mathrm{KH}_{2} \mathrm{PO}_{4}, 0.85 \% \mathrm{NaCl} ; \mathrm{pH} 7.3\right)$, adjusted to $50 \%$ transmittance at $680 \mathrm{~nm}$, serially diluted in PBS to $10^{-7}$, and $0.1 \mathrm{ml}$ from the $10^{-5}, 10^{-6}$, and $10^{-7}$ dilutions were spread plate on each medium. Values represent $\log _{10}$ estimates of the population of bacterial suspensions incubated at the indicated temperature and are the means of three replications from the $10^{-6}$ and $10^{-7}$ dilutions.

Table 1. Recovery efficiency of representative strains of Pseudomonas viridiflava on nine different media (KBC [16], KFT [1], BCBRVB [17], and T-0 through T-5) compared with King's medium B (KMB; 13)

\begin{tabular}{|c|c|c|c|c|c|c|c|c|c|}
\hline \multirow[b]{2}{*}{ Strain } & \multicolumn{9}{|c|}{ Recovery compared with KMB $(\%)^{\mathrm{a}}$} \\
\hline & KBC & KFT & BCBRVB & T-0 & T-1 & T-2 & T-3 & T-4 & T-5 \\
\hline$\overline{\mathrm{DD} 2}$ & 0.0 & 18.0 & 78.0 & 91.2 & 50.3 & 31.2 & 76.1 & 23.0 & 103.6 \\
\hline $\mathrm{R} 2$ & 0.0 & 0.0 & 6.6 & 129.8 & 94.2 & 7.3 & 95.0 & 1.1 & 88.2 \\
\hline $91-1$ & 0.0 & 2.1 & 52.9 & 97.4 & 59.5 & 27.9 & 103.5 & 19.6 & 88.2 \\
\hline 12322 & 0.0 & 76.8 & 71.2 & 39.0 & 85.2 & 27.3 & 67.6 & 39.3 & 59.6 \\
\hline 12323 & 0.0 & 24.6 & 7.8 & 43.5 & 47.6 & 28.5 & 53.4 & 41.2 & 55.2 \\
\hline $5777-4$ & 0.6 & 42.1 & 36.8 & 108.0 & 64.6 & 28.6 & 85.6 & 49.7 & 76.2 \\
\hline Mean & 0.1 & 27.3 & 42.2 & 85.2 & 66.9 & 25.1 & 80.2 & 29.0 & 78.5 \\
\hline
\end{tabular}

${ }^{a}$ Represents mean of three replicates. Bacteria were grown in nutrient broth for $24 \mathrm{~h}$, harvested by centrifugation, resuspended in $\mathrm{PBS}\left(0.01 \mathrm{M} \mathrm{K}_{2} \mathrm{HPO}_{4^{-}}\right.$ $\mathrm{KH}_{2} \mathrm{PO}_{4}, 0.85 \% \mathrm{NaCl} ; \mathrm{pH} 7.3$ ), adjusted to $50 \%$ transmittance at $680 \mathrm{~nm}$, serially diluted in PBS to $10^{-6}$, and $0.1 \mathrm{ml}$ from the $10^{-4}, 10^{-5}$, and $10^{-6}$ dilutions were spread plate on each medium. Plating efficiencies were determined by enumerating colonies of $P$. viridiflava on test media, dividing by number of colonies on KMB agar, and multiplying the quotient by 100. 
Data analysis. In all experiments, data were analyzed by PROC GLM and PROC STEPWISE statistical analysis programs using SAS software (19). The Waller-Duncan multiple range test $(P \leq 0.05)$ was used as a means separation test. Data were transformed as necessary $\left[\log _{10}(x+1)\right]$ for analysis.

\section{RESULTS AND DISCUSSION}

Medium development and plating efficiencies. Growth efficiencies of different strains of $P$. viridiflava on $\mathrm{KFT}, \mathrm{KBC}$, BCBRVB, and test media T- 0 through T-5 varied (Table 1). Most strains did not grow well on $\mathrm{KBC}$, and the range of growth efficiency on KFT ranged from $0.0 \%$ (onion strain R2) to $76.8 \%$ (ATCC 12322), and on BCBRVB from $6.6 \%$ (onion strain $\mathrm{R} 2$ ) to $78.0 \%$ (onion strain DD2). In general, onion strains DD2, R2, and 91-1 grew more efficiently on $\mathrm{T}-5$ (mean = 90.3\%) than did ATCC strains (mean = $57.4 \%$ ). All strains displayed less efficient growth on media containing both $\mathrm{D}(-)$ tartrate and rifampicin at $0.5 \mu \mathrm{g} / \mathrm{ml}$.

Evaluation of recovery of $P$. viridiflava from soil. $P$. viridiflava was not recovered from any soil samples plated on KMB or from nonamended soils on semiselective agar T-5 (Table 2). The bacterium was recovered on T-5 medium at the expected concentration from all four inoculumamended soil samples from Tift County (Fig. 1). This medium was selected for further evaluation because it was the most selective of those media that did not significantly affect growth efficiency and $P$. viridiflava raised the $\mathrm{pH}$ of the medium and produced a diagnostic pink zone around individual colonies. However, when tested with the two soils from sites A and B (Montgomery and Toombs, counties), the abundant growth of nontarget microflora prevented the easy detection of colonies of $P$. viridiflava (Table 2). Medium T-5 was developed in Tift County and originally was tested with soils that had no history of onion production. The two soils from which $P$. viridiflava was not recovered were from commercial sites with a history of continuous onion production. The different locations, different management practices, and different cropping histories most likely explain the differences in the microflora of these two soils. In all instances, bacterial identities were confirmed by a negative Gram, oxidase, and arginine dihydrolase reactions, slow and very weak utilization of sucrose, utilization of dl-lactate and $\mathrm{D}(-)$ tartrate, positive ice nucleation, and ability to rot onion.

Low temperature incubation. Observations of liquefaction of onions stored under refrigeration caused us to hypothesize that incubation at $5^{\circ} \mathrm{C}$ would support growth of $P$. viridiflava and inhibit competing microflora (8). Plating efficiencies were not significantly different when $P$. viridiflava strains DD2, R2, and PV 91-1 were grown on $\mathrm{KMB}$ and $\mathrm{T}-5$ media at temperatures ranging from 30 to $5^{\circ} \mathrm{C}$ (Table 3). Incubation at $5^{\circ} \mathrm{C}$ increased the time of growth to achieve a colony large enough for recognition and enumeration from 3 to 5 days at $30^{\circ} \mathrm{C}$ to 16 to 20 days. In addition, fluorescence was much weaker in plates of cultures grown at the lower temperatures. However, when a final concentration of $10^{1}$ or $10^{2} \mathrm{CFU}$ of $P$. viridi- flava per $\mathrm{ml}$ were placed in soil suspensions from Site A and assayed at both 30 and $5^{\circ} \mathrm{C}$, the pathogen was recovered only at $5^{\circ} \mathrm{C}$. The bacterium was detected $100 \%$ of the time when initial levels of inoculum were $10^{2} \mathrm{CFU} / \mathrm{ml} / 10 \mathrm{~g}$ soil (Fig. 2), but only $33 \%$ of the time when bacterial populations dropped to $10^{1} \mathrm{CFU} / \mathrm{ml} / 10 \mathrm{~g}$ soil (Table 4). This level of sensitivity should be adequate for most epidemiologi-

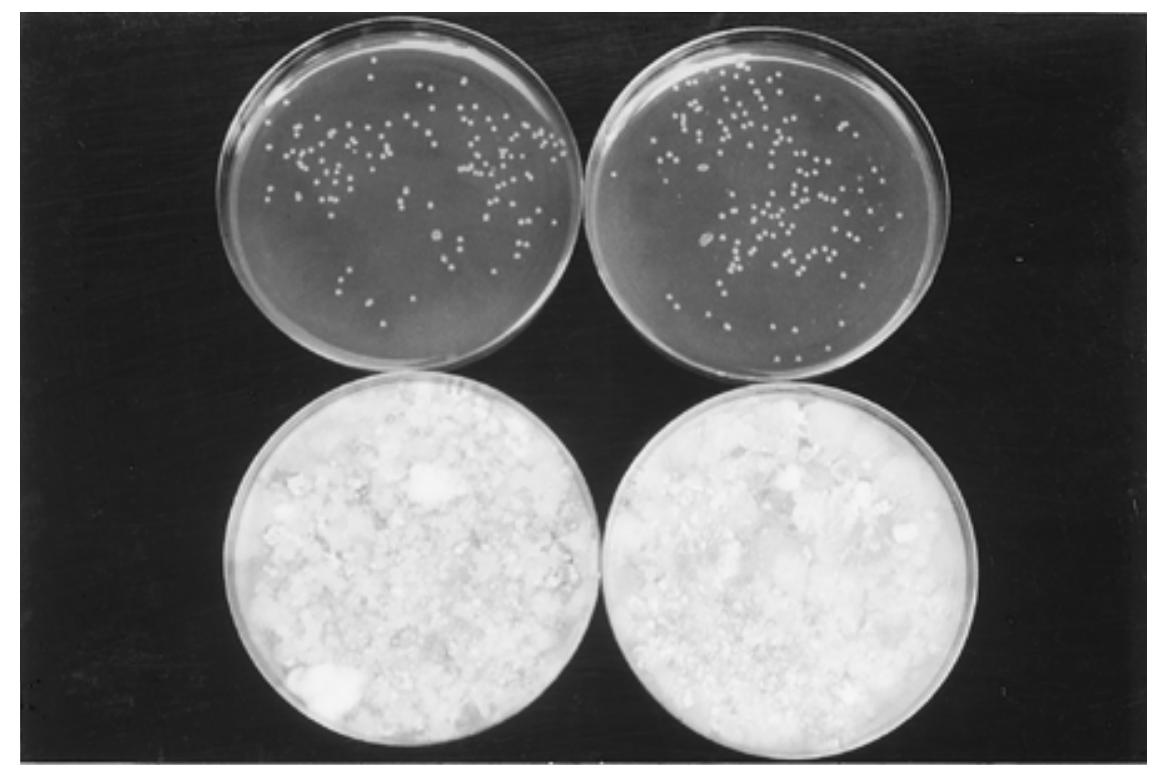

Fig. 1. Comparison between semiselective medium T-5 (upper) and standard growth medium King's Medium B (lower) for the isolation and enumeration of Pseudomonas viridiflava from nonsterile, artificially-infested soil. Darker areas surrounding CFU of $P$. viridiflava on medium T-5 are dark pink and contrast with the lighter, pale orange color of areas with no growth, or around some nontarget microflora.

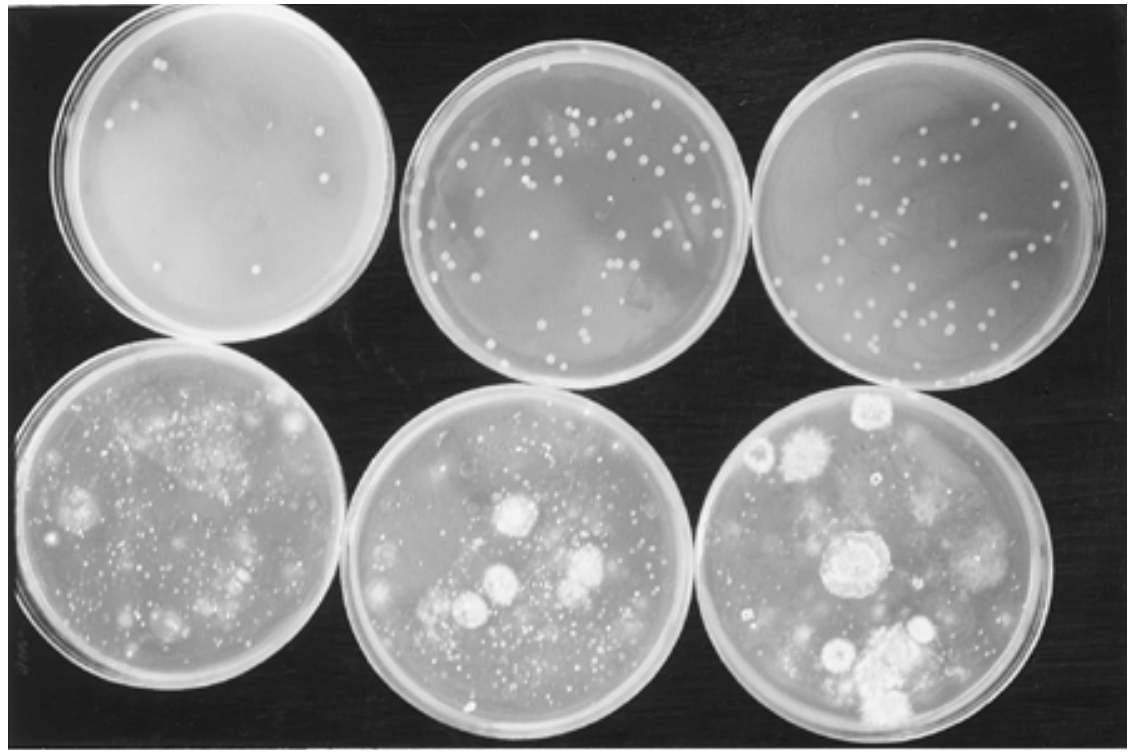

Fig. 2. Recovery of Pseudomonas viridiflava from artificially amended, nonsterile soil with a cropping history of onion-soybean, multi-crop rotation for 5 years and continuous onion cultivation for a minimum of 20 years. An essentially pure culture of $P$. viridiflava was recovered on semiselective medium $\mathrm{T}-5$ at $5^{\circ} \mathrm{C}$ (upper), compared with the highly diverse microflora obtained on the same medium at $30^{\circ} \mathrm{C}$ (lower) 
